\title{
INVESTIGATION OF PHYSICOCHEMICAL PARAMETERS TO ASSESS VARIABILITY OF GROUNDWATER QUALITY DUE TO SOLID WASTE DUMPING: A CASE STUDY
}

\author{
P.Vijayalakshmi ${ }^{1 \text { **and Marykutty Abraham }}{ }^{2}$ \\ ${ }^{1}$ Research Scholar and Assistant Professor, Department of Civil Engineering, Sathyabama \\ Institute of Science and Technology, Chennai, Tamilnadu, India. \\ ${ }^{2}$ Scientist E, CRSG, Sathyabama Institute of Science and Technology, \\ Chennai, Tamilnadu, India. \\ *E-mail: vijayalakshmipanneerselvam@yahoo.co.in
}

\begin{abstract}
Groundwater samples of bore wells (BW), open wells (OW), and Hand Pumps (HP) collected from different locations at Periyaeri landfill at Chrompet,Chennai,Tamilnadu were analyzed for physicochemical Parameters such as $\mathrm{pH}$, Electrical Conductivity (EC), Chloride (Cl), Total Hardness (TH), Total Dissolved Solids (TDS), Iron (Fe), Zinc (Zn), The groundwater samples were studied during pre-monsoon seasons (2017) from 12 different places. The impact of leachates on groundwater quality was evaluated. Each parameter was compared with a standard permissible limit as prescribed by Bureau of Indian Standards (BIS)and World Health Organization (WHO) which indicates that most of the groundwater samples are not potable for drinking purposes. The study indicates that pollution of ground water near the dump site area is increasing at alarming rates and it has created a serious threat to human health.
\end{abstract}

Keywords: landfill/dumpsite, groundwater, municipal solid waste, physicochemical

(C) RASĀYAN. All rights reserved

\section{INTRODUCTION}

Water is essential to sustain life and one of the most vital resources.. Study on quantity and quality of water resources is very important for its proper usage and management. ${ }^{1}$ In developing countries, the environmental and public health problem is increasing due to the generation of solid waste. ${ }^{2}$ A large quantity of solid waste generated in and around Chennai urban areas are dumped nearer to Pallavaram landfill site and the parameters of water are not in the acceptable limit in accordance with the IS 10500 Drinking Water Quality Standards which concluded that the contamination is because of dumped solid waste materials in the area. ${ }^{3}$ The cause for the Groundwater contamination in the nearby areas of the dumpsite is because of leachate that consists of decomposing organic matter combined with iron, mercury, lead, zinc and other metal. ${ }^{4}$ Implementing new technology like using permeable reactive barrier near the effluent discharged area and around the solid waste dumping area we can minimize the groundwater contamination. ${ }^{5}$ The groundwater quality changed due to anthropogenic and natural influences. ${ }^{6}$ The reason for the high concentration of major ions and chromium in groundwater is the use of chemicals, such as sodium chloride, sodium sulphate, chromium sulphate etc. during the tanning processes. ${ }^{7}$ Pre-monsoon period water quality is above the desirable limit and during the post-monsoon period the water is potable. Quality of groundwater changes because of the addition of rainwater into the groundwater regime through infiltration. ${ }^{8}$

\section{Study Area}

This study has been carried out in Chromepet area, located in the southern part of Chennai city which is $13 \mathrm{~km}$ and $20 \mathrm{Km}$ away from Bay of Bengal and Chennai city respectively. The dumping site (recently closed) is located at latitudes $12^{\circ} 57^{\prime} 21.11^{\prime \prime} \mathrm{N}$, longitude $80^{\circ} 09^{\prime} 1.00^{\prime \prime}$ E. The dumping site ground 
elevation is $17 \mathrm{~m}$ above mean sea level. Figure- 1 shows the location of study area. The climate of the area is with low humidity and high temperature.The temperature is around $20^{\circ} \mathrm{C}$ and $44^{\circ} \mathrm{C}$ during winter and summer season respectively. Nearly $40 \%$ of the annual rainfall, which is about $1200 \mathrm{~mm}$ more than $60 \%$ of the annual rainfall from October to December, is contributed by southwest monsoon from June to September and northeast monsoon from October to December respectively.

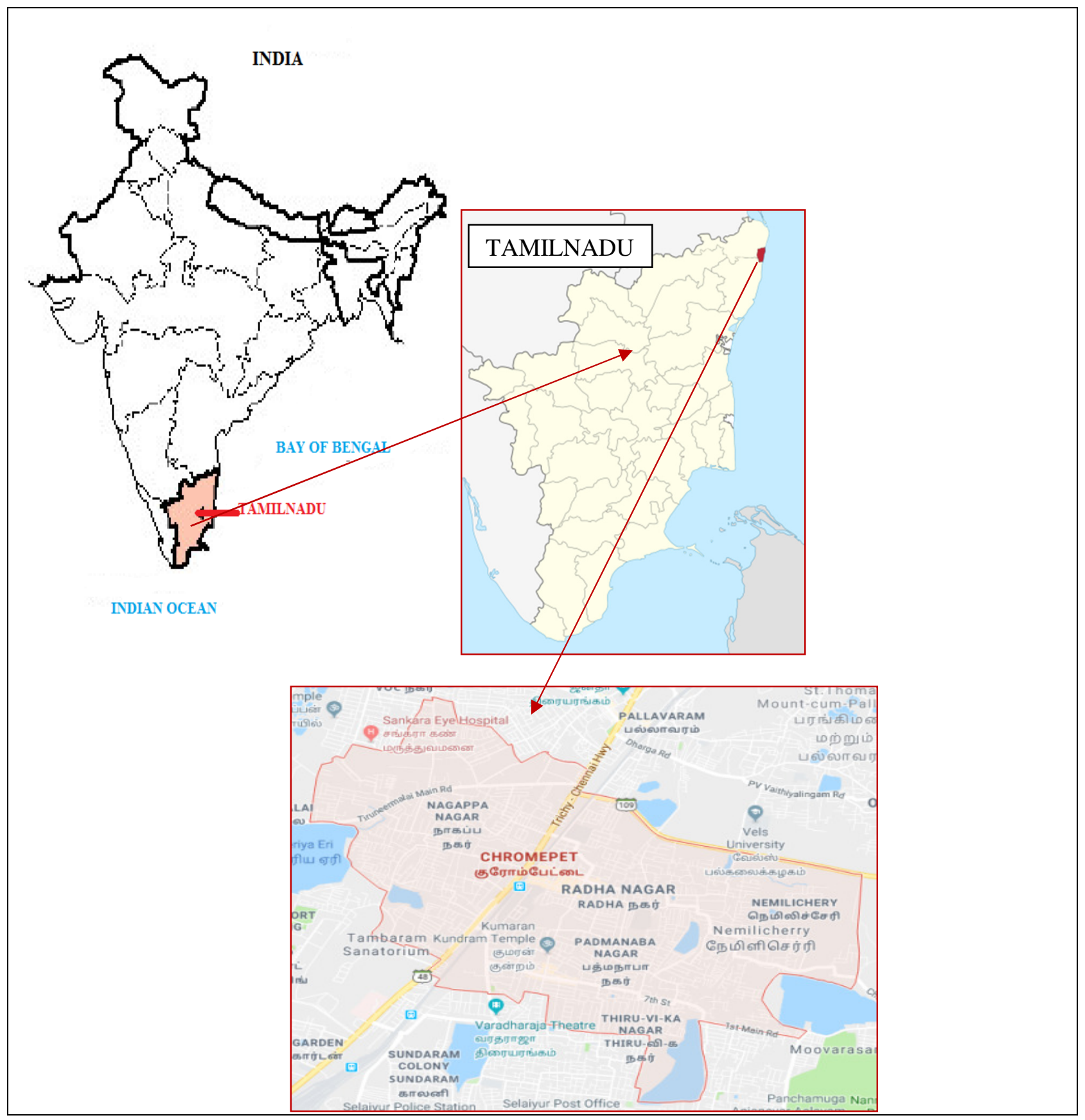

\section{Samples Collection}

Fig.-1: Location map of the study area

Twelve water samples were collected during January 2017 to June 2017 (Pre Monsoon) from the represented Open well, Hand pumps, Bore wells of different locations near the Eastern and Southern side solid waste dumping site, which are under use at $0.5 \mathrm{~m}$ below the water table, and were pumped more 
RASĀYAN J. Chem.

Vol. 11 | No. 2 |728 - 734 | April - June | 2018

than 5 min. Methods of collection and analysis of water samples followed are the same as given by APHA $^{14}$ methods. 1-liter capacity polythene bottles were used to the water samples. In the laboratory, the bottles were thoroughly washed with acid, and then with distilled water before filling the bottle with the water sample. To avoid air bubble, the container was filled fully. All the information required by the laboratory was marked properly with waterproof materials. Specifications of sampling points are shown in Table- 1.

\section{Analysis of Groundwater Samples}

All the collected samples were analyzed for $\mathrm{pH}, \mathrm{EC}, \mathrm{Cl}, \mathrm{TH}, \mathrm{TDS}, \mathrm{Fe}, \& \mathrm{Zn}$ using standard methods. The results are tabulated (Table-2) and compared with drinking water quality standards as recommended by $\mathrm{BIS}^{15}$ and $\mathrm{WHO}^{16}$ (Table-3).To monitor the drinking water for healthy life is mandatory. Some parameter values are exceeded the desirable value suggested by WHO and BIS standards.

Table -1: Site specification for samples

\begin{tabular}{|c|c|c|c|c|c|c|c|}
\hline S.No. & $\begin{array}{l}\text { Sample } \\
\text { Code }\end{array}$ & $\begin{array}{c}\text { Source/Type } \\
\text { of well }\end{array}$ & $\begin{array}{l}\text { Location Name } \\
\text { (Sample Places) }\end{array}$ & $\begin{array}{c}\text { Distance from } \\
\text { Landfill Site }(\mathrm{m})\end{array}$ & Latitude & Longitude & $\begin{array}{l}\text { Depth } \\
\text { (m) }\end{array}$ \\
\hline 1 & S1 & BW & Ganapathy Nagar & 162 & $12^{\circ} 57^{\prime} 17.20^{\prime \prime} \mathrm{N}$ & $80^{\circ} 09^{\prime} 3.14^{\prime \prime} \mathrm{E}$ & 9 \\
\hline 2 & $\mathrm{~S} 2$ & BW & Canapathy Nagar & 233 & $12^{\circ} 57^{\prime} 14.44^{\prime \prime} \mathrm{N}$ & $80^{\circ} 09^{\prime} 1.73$ "E & 75 \\
\hline 3 & S3 & $\mathrm{HP}$ & Ganapathy Nagar & 252 & $12^{\circ} 57^{\prime} 13.71^{\prime \prime} \mathrm{N}$ & $80^{\circ} 09^{\prime} 1.69$ "E & 84 \\
\hline 4 & S4 & BW & Rajapalayam colony. & 215 & $12^{\circ} 57^{\prime} 14.98$ "N & $80^{\circ} 08^{\prime} 59.97^{\prime \prime} \mathrm{E}$ & 76 \\
\hline 5 & S5 & BW & Rajapalayam colony. & 198 & $12^{\circ} 57^{\prime} 15.58^{\prime \prime} \mathrm{N}$ & $80^{\circ} 08^{\prime} 59.61^{\prime \prime} \mathrm{E}$ & 68 \\
\hline 6 & S6 & BW & Jesudaran street. & 208 & $12^{\circ} 57^{\prime} 15.81^{\prime \prime} \mathrm{N}$ & $80^{\circ} 08^{\prime} 57.78^{\prime \prime} \mathrm{E}$ & 107 \\
\hline 7 & S7 & OW & Vallalperumaltheru, & 265 & $12^{\circ} 57^{\prime} 14.44$ "N & $80^{\circ} 09^{\prime} 1.69^{\prime \prime} \mathrm{E}$ & 7 \\
\hline 8 & S8 & $\mathrm{BW}$ & Ganapathipuram & 526 & $12^{\circ} 57^{\prime} 14.44$ "N & $80^{\circ} 09^{\prime} 1.69$ "E & 91 \\
\hline 9 & S9 & BW & Ganapathipuram & 525 & $12^{\circ} 57^{\prime} 14.44$ "N & $80^{\circ} 09^{\prime} 1.69^{\prime \prime} \mathrm{E}$ & 91 \\
\hline 10 & $\mathrm{~S} 10$ & HP & Balamurugan street & 309 & $12^{\circ} 57^{\prime} 11.52^{\prime \prime} \mathrm{N}$ & $80^{\circ} 09^{\prime} 04.14^{\prime \prime} \mathrm{E}$ & 91 \\
\hline 11 & $\mathrm{~S} 11$ & $\mathrm{BW}$ & Balachandran House & 282 & $12^{\circ} 57^{\prime} 12.36 " \mathrm{~N}$ & $80^{\circ} 09^{\prime} 00.94 " \mathrm{E}$ & 107 \\
\hline 12 & $\mathrm{~S} 12$ & OW & Ganapathy Nagar. & 150 & $12^{\circ} 57^{\prime} 16.65^{\prime \prime} \mathrm{N}$ & $80^{\circ} 09^{\prime} 02.33^{\prime \prime E}$ & 8 \\
\hline
\end{tabular}

BW - Bore well, HP - Hand pump, OW - Open well

Table-2: Physico-chemical characteristics of groundwater in the study area(All parameters, units are in $\mathrm{mg} / \mathrm{L}$ except $\mathrm{EC}$ in $\mu \mathrm{S} / \mathrm{cm}$ and $\mathrm{pH})$

\begin{tabular}{c|c|c|c|c|c|c|c}
\hline \multirow{2}{*}{ Sample Code } & \multicolumn{7}{|c}{ Characteristic (Mean of Jan, Feb, Mar \& May 2017) } \\
\cline { 2 - 8 } & pH value & Conductivity & Chloride & TH & TDS & Iron & Zinc \\
\hline S1 & 6.94 & 1877 & 140 & 1745 & 3108 & 0.16 & 0.25 \\
\hline S2 & 7.47 & 1911 & 144 & 422 & 1071 & 0.2 & 0.41 \\
\hline S3 & 7.51 & 2020 & 264 & 447 & 1077 & 0.22 & 0.29 \\
\hline S4 & 7.7 & 2081 & 292 & 597 & 1087 & 0.12 & 0.22 \\
\hline S5 & 7.55 & 2331 & 238 & 516 & 1441 & 0.23 & 0.47 \\
\hline S6 & 7.47 & 1717 & 221 & 475 & 901 & 0.19 & 0.46 \\
\hline S7 & 7.8 & 1794 & 170 & 419 & 738 & 0.24 & 0.41 \\
\hline S8 & 7.53 & 2115 & 229 & 524 & 1037 & 0.29 & 0.5 \\
\hline S9 & 7.65 & 2010 & 228 & 500 & 1042 & 0.26 & 0.47 \\
\hline S10 & 7.55 & 1674 & 218 & 429 & 853 & 0.22 & 0.4 \\
\hline S11 & 7.76 & 1657 & 205 & 437 & 854 & 0.25 & 0.39 \\
\hline S12 & 7.72 & 1666 & 211 & 461 & 842 & 0.23 & 0.31 \\
\hline $\begin{array}{c}\text { Min. Conc. } \\
\text { (Average) }\end{array}$ & 7.09 & 1707 & 137 & 349 & 946 & 0.13 & 0.23 \\
\hline $\begin{array}{c}\text { Max. Conc. } \\
\text { (Average) }\end{array}$ & 8.15 & 2437 & 294 & 746 & 1517 & 0.34 & 0.57 \\
\hline Mean & 7.554167 & 1904.416667 & 213.333333 & 581.000000 & 1170.916667 & 0.217500 & 0.381667 \\
\hline Std. Deviation & 0.310301 & 204.382974 & 42.858942 & 354.511871 & 609.343972 & 0.043684 & 0.088882 \\
\hline
\end{tabular}


RASĀYAN J. Chem.

Vol. 11 | No. 2 |728 - 734 | April - June | 2018

Notes: Min - minimum, Max - maximum, SD - standard deviation, Conc. - Concentration,

Table-3: Water quality standards as recommended by BIS and WHO

\begin{tabular}{c|l|c|c|c}
\hline \multirow{2}{*}{$\begin{array}{c}\text { Sl. } \\
\text { No. }\end{array}$} & \multirow{2}{*}{$*$ Parameters } & \multicolumn{2}{|c|}{ BIS standards IS 10500 : 2012) } & \multirow{2}{*}{ WHO (2002) } \\
\cline { 3 - 4 } & & $\begin{array}{c}\text { Requirement } \\
\text { Acceptable Limit })\end{array}$ & $\begin{array}{c}\text { The permissible limit in the } \\
\text { Absence of Alternate Source }\end{array}$ & \\
\hline 1 & $\mathrm{pH}$ & $6.5-8.5$ & $6.5-8.5$ & $6.5-9.2$ \\
\hline 2 & EC $(\mu \mathrm{S} / \mathrm{cm})$ & - & - & - \\
\hline 3 & TDS $(\mathrm{mg} / \mathrm{l})$ & 300 & 1,500 & 250 \\
\hline 4 & TH $(\mathrm{mg} / \mathrm{l})$ & 300 & 600 & 300 \\
\hline 5 & Chlorides $(\mathrm{mg} / \mathrm{l})$ & 250 & 1000 & 200 \\
\hline 6 & Iron $(\mathrm{mg} / \mathrm{l})$ & 0.3 & 1 & 0.3 \\
\hline 7 & Lead $(\mathrm{mg} / \mathrm{l})$ & 0.05 & No relaxation & 5 \\
\hline 8 & Zinc $(\mathrm{mg} / \mathrm{l})$ & 5 & 15 & 5 \\
\hline
\end{tabular}

\section{RESULTS AND DISCUSSION}

\section{pH}

$\mathrm{pH}$ of the water affects by the combination of carbon dioxide with water form carbonic acid. ${ }^{6} \mathrm{pH}$ is a term to express the intensity of acidic or alkaline conditions and an important parameter in assessing the water quality. The average $\mathrm{pH}$ of the groundwater samples ranges from 6.94 to 7.8 in pre-monsoon 2017(Figure- 2). The $\mathrm{pH}$ values of all groundwater samples collected are within the range of desirable and permissible limit of BIS and WHO standards. The higher value of $\mathrm{pH}$ may cause difficulties in the chlorination process for disinfection of drinking water. ${ }^{17}$

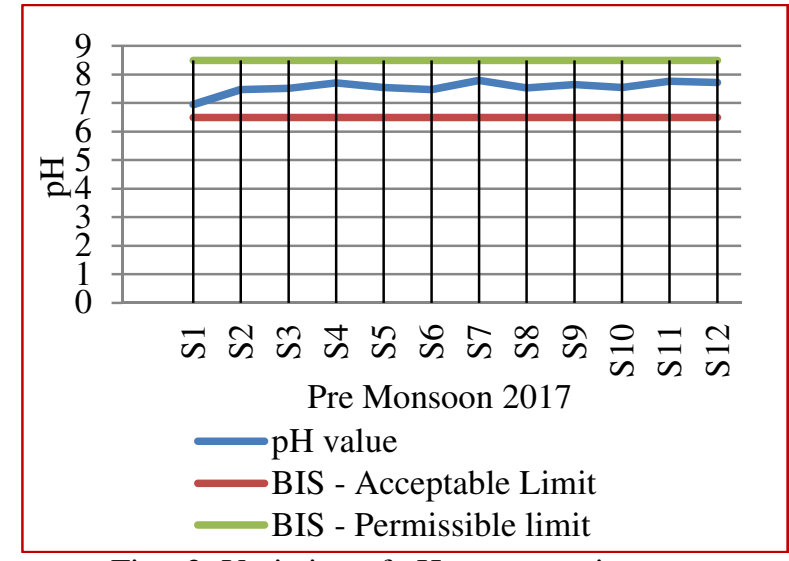

Fig. -2: Variation of $\mathrm{pH}$ concentration

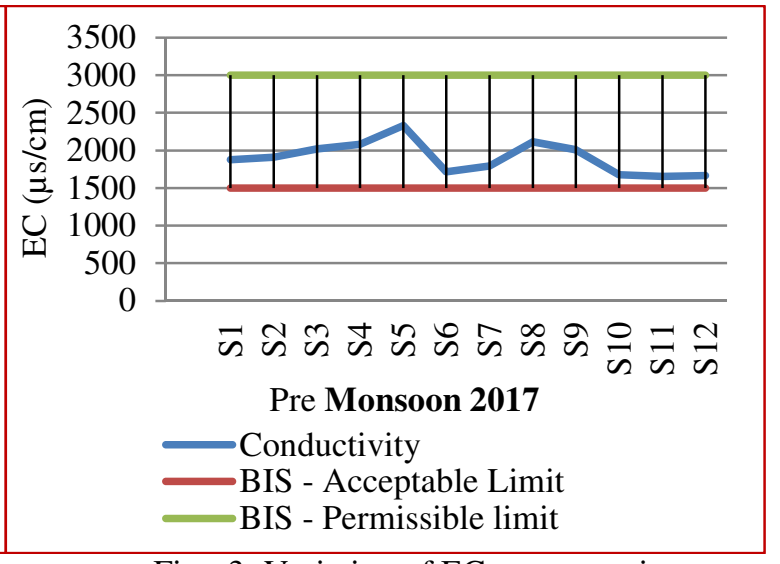

Fig. -3: Variation of EC concentrations

\section{Electrical Conductivity (EC)}

At a temperature of $25^{\circ} \mathrm{C}$, the ability of $1 \mathrm{~cm}^{3}$ of water to conduct electric current measured by micro Siemens per centimeter $(\mu \mathrm{S} / \mathrm{cm})$ is electrical conductivity and it depends on the soluble salts concentration and the water temperature. ${ }^{7}$ An increase of one degree Celsius causes an increase in electrical conductivity by two $\%{ }^{8}$ The value of electrical conductivity in the study was very high. This may be due to the quantity of skins and hides processed and the amounts of salts used and solid waste dumping site. Higher EC indicates the acid-base and the enrichment of salts in the groundwater. ${ }^{9}$ EC of all collected water samples exceed the permissible limit $(1500 \mu \mathrm{S} / \mathrm{cm}) .{ }^{10}$

\section{Chlorides (Cl)}

A natural and anthropogenic source such as run-off containing salts. The use of inorganic fertilizers, leachates, the effluent of the septic tank, animal feeds, effluents of industries, irrigation drainage and 
intrusion of sea water in coastal areas results in chlorides in groundwater, reported by Department of National Health and Welfare, Canada. ${ }^{11}$

Except for S1, S2 \& S7, the mean concentration of the groundwater samples show above the acceptable limits $250 \mathrm{mg} / \mathrm{l}, 200 \mathrm{mg} / \mathrm{l}$ as per BIS and WHO respectively. Hypertension, stroke, osteroporosis, renal stones and asthma in human beings may cause by consumption of chloride concentration water. The increase of chloride level in water is injurious to people suffering due to heart and kidney diseases. ${ }^{9}$ Chlorides are found in the form of sodium chloride in the groundwater imparts a salty taste.

Chloride concentrations for the groundwater samples showed variations from 140 ( $1^{\text {st }}$ station) to $292 \mathrm{mg} / 1$ ( $4^{\text {th }}$ station) with an average minimum and maximum value of $137 \mathrm{mg} / \mathrm{l}, 292 \mathrm{mg} / \mathrm{l}$ respectively. An excess amount of chloride in water has been taken as an Index of pollution.As per Stuyfzand 1989the samples S3, S4, S5, S8 \& S9 are categorized as salt (i.e 42\%) and the samples, S1, S2, S6, S7, S10, S11, \& S12 are categorized as Brackish-salt (i.e 58\%).

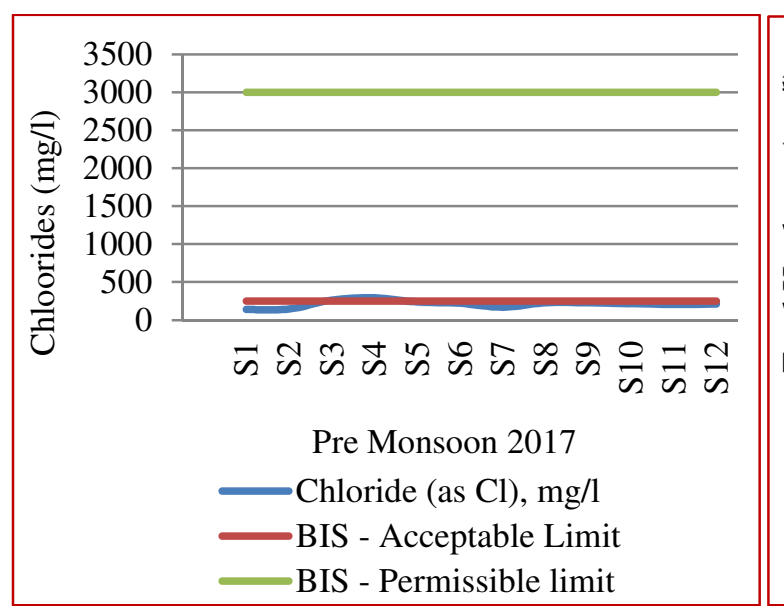

Fig.-4: Variation of Chloride

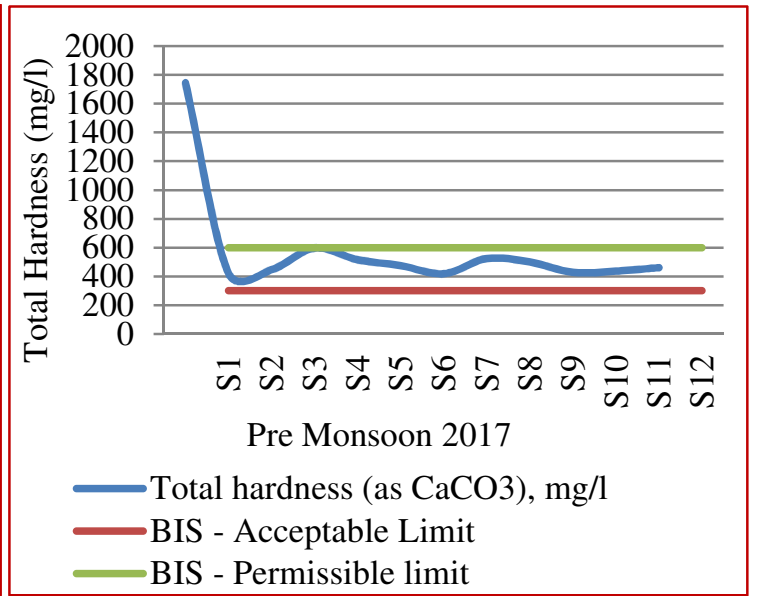

Fig.-5: Variation of Total Hardness

\section{Total Hardness (TH)}

Temporary and permanent is due to the soap action in water by the precipitation of $\mathrm{Ca}$ and $\mathrm{Mg}$ salts. Temporary hardness is due to the presence of calcium carbonate and gets removed when boiling water. Permanent hardness is caused by the presence of $\mathrm{Ca}$ and $\mathrm{Mg}$ which gets removed by ion exchange processes. ${ }^{25}$

The presence of dissolved calcium and magnesium salts generally carbonates results of the hardness of groundwater. Groundwater sample concentration exceeds the $300 \mathrm{mg} / \mathrm{l}$ and fall in the very hard water category. Presence of too much hardness in the water makes people using the water prone to diseases like kidney stones and other aliments. ${ }^{12}$

All the sample concentration are with the limits, only the sample one which has been taken near the dumpsite i.e., the boundary of the dump site give higher value (Figure 5).

\section{Total Dissolved Solids (TDS)}

Increase in the dissolved solids may be the results of several hydro chemical processes. Movement of groundwater through rocks containing soluble mineral materials will also increase the dissolved solids. The concentration of water by evaporation, contamination of water due to industrial and municipal waste disposals, can cause an increase in the dissolved solids. ${ }^{13}$ The presence of excessive solids in water indicates pollution which can lead to a laxative effect. ${ }^{18}$

On the basis of Davis and DeWiest 1966 classification, the study area groundwater average concentration of S6, S7, S10, S11\& S12 within the permissible limit of drinking (500-1000mg/l). And S2, S3, S4, S5 S8 \&S9 are unfit for irrigation (up to $1000 \mathrm{mg} / \mathrm{l}$ ) and $\mathrm{S} 1$ are unfit for irrigation and drinking (>3000mg/l). 
Classification based on Freeze and Cherry $42 \%$ of groundwater samples (S2, S6, S10, S11 \& S12) came under fresh water category $(0-1000 \mathrm{mg} / \mathrm{l})$ while $58 \%$ of them $(\mathrm{S} 1, \mathrm{~S} 3, \mathrm{~S} 4, \mathrm{~S} 5 \mathrm{~S} 7, \mathrm{~S} 8$ \& S9) belonged to brackish water category.

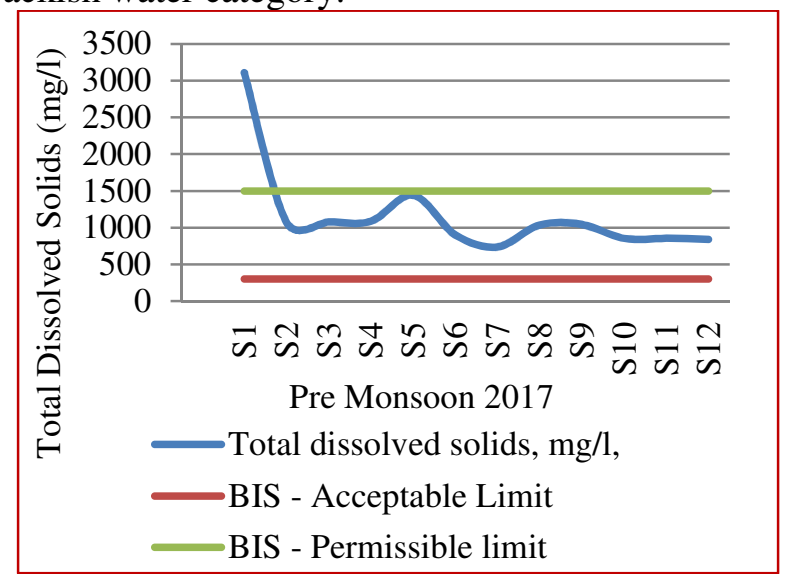

Fig.-6: Variation of Total Dissolved Solids

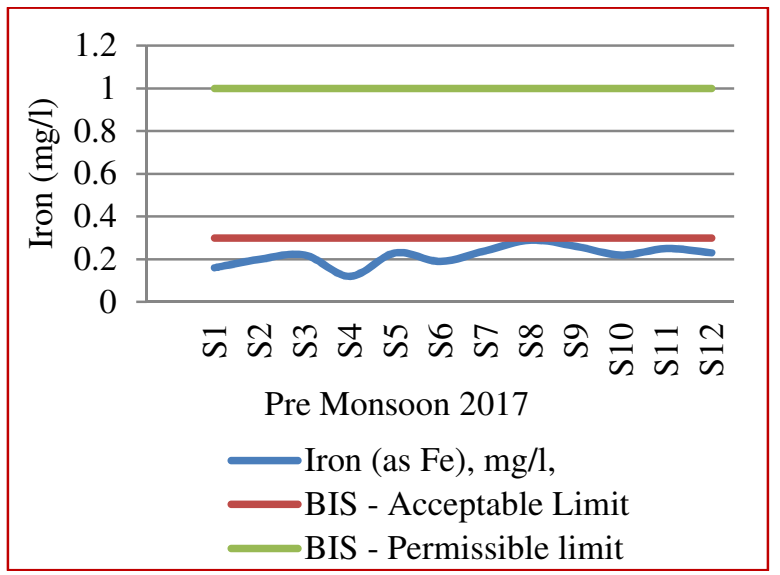

Fig.-7: Variation of Iron

\section{Iron}

Even though the Iron is an essential element in human, it has little health hazard, and still considered as a nuisance in excessive quantities. Also not suitable for processing of food, beverages, dyeing, bleaching, etc., and causes staining of clothes and utensils. ${ }^{25}$ The concentration of Iron (Fe) in the groundwater samples are well below the BIS \& WHO permissible limit $(0.3 \mathrm{mg} / \mathrm{l})$. Variation of Iron concentration is shown in Figure- 8. Bitter and astringent taste caused by high iron concentrations. ${ }^{21}$

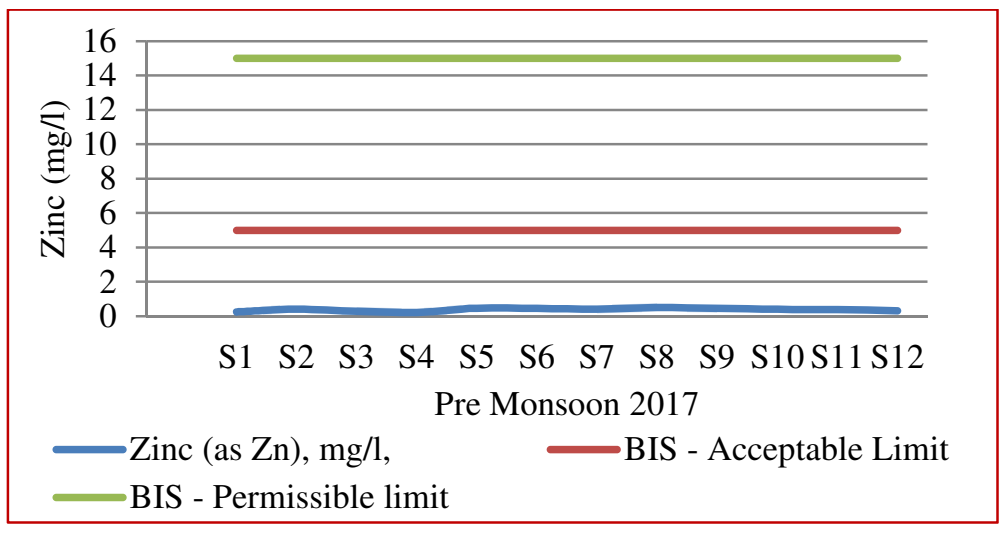

Zinc (Zn)

Fig.-8: Variation of Zinc

The concentration of zinc in water has been found to have low toxicity to man. Only prolonged consumption of large doses can result in fatigue, dizziness and neutropenia. ${ }^{12}$ Zinc concentration in the study area is less than the permissible limit. For prenatal and postnatal development zinc is an essential mineral and deficiency affects about two billion people in the developing world and is associated with many diseases. ${ }^{21}$

\section{CONCLUSION}

The unsystematic disposal and raw state dumping of municipal solid waste are considered as a desperate practice. Except for $\mathrm{pH}$, Physico-chemical parameters analyzed for the study area exceeded the permissible limits. The presence of heavy metals Iron and Zinc in groundwater samples indicated that there is considerable contamination by migration of leachate from the open dumping site. Eventually, all 
results show, that the Periyaeri landfill site founded a serious threat to local aquifers. Therefore there is a need for some treatment before usage of ground water and also the area needs protection from further contamination. Since, the landfill is closed recently and is fully residential area now; utmost care is needed to protect the groundwater quality.

\section{REFERENCES}

1. Gopal Krishan, Surjeet Singh, C.P. Kumar, Suman Gurjar and N.C. Ghosh, J. Earth Sci. Clim. Change,,7(3), 341(2016), DOI: 10.4172/2157-7617.1000341

2. S. Kanmani and R. Gandhimathi, Appl Water Sci., 3, 387(2013), DOI: 10.1007/s13201-013-0089-y

3. N. Raman and D. Sathiyanarayanan, Rasayan Journal of Chemistry, 4(2), 481(2011).

4. S. Shenbagaran, IOSR Journal Of Environmental Science, Toxicology And Food Technology, 4(2), 1 (2013)

5. P. Vijayalakshmi, C. Sandeep Kumar Reddy and G. Tharunm, Indian Journal of Science and Technology, 10(27), 1(2017), DOI: 10.17485/ijst/2017/v10i27/100563

6. V. Karpagam and K. Ramesh, International Journal of Engineering Technology, Management and Applied Sciences,3(7), 123(2015)

7. C. E. Boyd, Water Quality An Introduction, Kluwer Academic Publisher, USA, 330(2000).

8. J. D. Hem, USGS Water Supply Paper 2254, 17-120 ((1985).

9. K. Ramesh and V. Thirumangai, International Journal of Research in Engineering and Technology, 4(1),63(2014)

10. K. Brindha and L. Elango, Water Resour. Manage., 26, 1747(2012)

11. Department of National Health and Welfare, Canada. Guidelines for Canadian Drinking Water Quality. Supporting documentation. DNHW: Ottawa, Canada, 1978.

12. N. Ravishankar and S. Poongothai, Indian Science Tsunami Hazards, 27(1),47(2008).

13. N. C. Mondal, V. K. Saxena and V. S. Singh, India Environ Geol, 48, 149(2005)

14. APHA (1998) Standard Methods for the Examination of Water and Wastewater (17th ed), American Public Health Association, Washington

15. Bureau of Indian Standards (BIS):1991 Indian Standard Specification for Drinking Water IS: 10500 $2-4$

16. World Health Organization (WHO) (2002) Guideline for Drinking Water Quality. Health Criteria and Other Supporting Information, World Health Organization, Geneva, pp 940-949

17. M. Suresh Kumar, R. Sivakumar and M. Nagarajan, Rasayan Journal of Chemistry, 9(3), 454(2016)

18. P. Thamilarasu and R. Sharmila, , Rasayan Journal of Chemistry, 8(1), 92(2015)

19. Oladele Osibanjo and Adebola A. Adeyi, Int. J. Water, 11(1), 44(2017)

20. Rubia Khan and D. C. Jhariya, Journal geological society of India, 90, 69(2017), DOI: 10.1007/s12594-017-0665-0

21. Er. PoorvaKhawaskar, Seema Jagtap, International Journal of Recent Innovation In Engineering And Research, 2(12), 1(2017)

22. R. Prem Sudha, A, R. N. Umaa, K. Muralia and Meiaraj, International Journal Of Chemical Sciences, 14(1), 229(2016)

23. T. W. Behailu, T. S. Badessa and B. A. Tewodros, Journal of Analytical \&Bioanalytical Techniques, 8(5), 1(2017), DOI: 10.4172/2155-9872.1000379

24. R. N. Uma, R. PremSudha and K. Murali, Int. J. Chem. Sci., 14(4), 3265(2016)

25. S. K. Nag1 and Shreya Das, Appl Water Sci., 7, 2787(2017), DOI: 10.1007/s13201-017-0530-8

26. Rahim Barzegar, Asghar Asghari Moghaddam, and Evangelos Tziritis, Appl. Water Sci., 7, 3997(2017), DOI: 10.1007/s13201-017-0550-4

[RJC-2051/2018] 